\title{
Comparison of Planted Soil Infiltration Systems for Treatment of Log Yard Runoff
}

\author{
Asa Hedmark ${ }^{1,2}$, Miklas Scholz ${ }^{3 *}$, Par Aronsson $^{4}$, Torbjorn Elowson ${ }^{1}$
}

\begin{abstract}
Treatment of $\log$ yard runoff is required to avoid contamination of receiving watercourses. The research aim was to assess if infiltration of log yard runoff through planted soil systems is successful and if different plant species affect the treatment performance at a fieldscale experimental site in Sweden (2005 to 2007). Contaminated runoff from the log yard of a sawmill was infiltrated through soil planted with Alnus glutinosa (L.) Gärtner (common alder), Salix schwerinii $\times$ viminalis (willow variety "Gudrun"), Lolium perenne (L.) (rye grass), and Phalaris arundinacea (L.) (reed canary grass). The study concluded that there were no treatment differences when comparing the four different plants with each other, and there also were no differences between the tree and the grass species. Furthermore, the infiltration treatment was effective in reducing total organic carbon $(55 \%)$ and total phosphorus $(45 \%)$ concentrations in the runoff, even when the loads on the infiltration system increased from year to year. Water Environ. Res., 82 (2010).
\end{abstract}

KEYWORDS: water management, water quality, treatment efficiency, total organic carbon, total phosphorus, water cycle, infiltration, wood industry, sawmill, Sweden.

doi: $10.2175 / 106143009 \times 12529484815917$

\section{Introduction}

Contaminated runoff from log yards is generated when water comes into contact with wood, woody debris, equipment, and vehicles at outdoor wood sorting, processing, and storage facilities (Woodhouse and Duff, 2004). It also is common to sprinkle logs with water to protect them from cracking and biological attack (Hedmark and Scholz, 2008). The contamination of the runoff depends on the specific conditions at the individual log yard; for example, the species of tree stored on the log yard, proportion of the runoff that has come in contact with stored wood, and dilution or pretreatment of the runoff before sampling. Typical runoff has the following characteristics (Hedmark and Scholz, 2008; Hedmark et al., 2009): high concentration of organic substances, some

\footnotetext{
${ }^{1}$ Swedish University of Agricultural Sciences, Department of Forest Products, Uppsala, Sweden.

${ }^{2}$ Scottish Environment Protection Agency, The Castle Business Park, Stirling, United Kingdom.

${ }^{3}$ Institute for Infrastructure and Environment, School of Engineering, The King's Buildings, The University of Edinburgh, Edinburgh, United Kingdom.

${ }^{4}$ Swedish University of Agricultural Sciences, Department of Crop Production Ecology, Uppsala, Sweden.

* Institute for Infrastructure and Environment, School of Engineering, William Rankine Building, Mayfield Road, The King's Buildings, The University of Edinburgh, Edinburgh EH9 3JL, Scotland, United Kingdom; e-mail:m.scholz@ed.ac.uk.
}

of which can be toxic to aquatic plants and animals (100 to $6000 \mathrm{mg} / \mathrm{L}$ ); relatively high amount of total suspended solids (TSS) (100 to $5000 \mathrm{mg} / \mathrm{L}$ ); medium to high concentrations of total phosphorus $(0.5$ to $5 \mathrm{mg} / \mathrm{L})$; relatively low concentration of total nitrogen $(0.5$ to $2.5 \mathrm{mg} / \mathrm{L})$; low concentrations of (heavy) metals ( 0.00 to $0.05 \mathrm{mg} / \mathrm{L}$ per metal); and low to neutral $\mathrm{pH}$ (4 to 8$)$.

The objectives of this paper were to assess if infiltration of $\log$ yard runoff through soil systems reduces the concentrations of pollutants, such as organic carbon and phosphorus, in the runoff, and if different species of plants affect the treatment performance when log yard runoff is infiltrated through vegetated soil systems.

\section{Experimental Setup and Methods}

The study site is located in a field near Heby Sawmill in central Sweden $\left(59^{\circ} 56^{\prime} \mathrm{N}, 16^{\circ} 50^{\prime} \mathrm{E}\right)$. The area previously had been used for agricultural production. Soil analysis from another experimental site in close vicinity of this study site showed that the organic matter in the topsoil was $3.8 \%$ (by mass) and that the $\mathrm{pH}$ increased from 5.5 in the topsoil to 7.0 at a soil depth of $2.5 \mathrm{~m}$. The soil texture was loam (18\% clay, $38 \%$ silt, and $44 \%$ sand), which is known to have a relatively high soil water retention capability and adsorptivity and therefore can easily adsorb inorganic chemicals, such as phosphate (Scholz, 2006). The soil texture was relatively uniform throughout the profile. No surface runoff or ponding was observed, and drainage was sufficient to allow for good infiltration. Furthermore, no cracking or fracturing of the soil surface was observed.

The site consisted of eight square $(20 \mathrm{~m} \times 20 \mathrm{~m})$ and flat planted soil infiltration systems or compartments (called plots from here onwards), covering a total area of $40 \times 80 \mathrm{~m}$. The plots were arranged in a matrix of two rows, with four columns each. The two plots of the first column were planted with A. glutinosa and $S$. schwerinii $\times$ viminalis, respectively. The following two plots of the second column were planted with $S$. schwerinii $\times v i$ minalis and A. glutinosa, in that order. The plots of the third column were planted with $P$. arundinacea and $L$. perenne, respectively. Finally, the remaining plots of the last column were planted with $L$. perenne and $P$. arundinacea, correspondingly. No buffer strips between the plots and no replicate plots were constructed.

During May and June 2003, five standard drainage pipes (outer and inner diameters of 74 and $65 \mathrm{~mm}$ ) per plot were placed $0.9 \mathrm{~m}$ below ground level. The slots in the pipes were covered with a 10$\mu \mathrm{m}$ polyester mesh to prevent clogging. Gravel was placed around the pipes, and most of the previously removed soil was put back again. The drainage system was designed to drain each flat plot separately. Water could not drain easily from one plot into the next, as a result of the relatively good soil drainage characteristics.

Water Environment Research, Volume 82-Copyright ( 2010 Water Environment Federation Uncorrected Page Proofs 
The distance between the drainage pipes was $4 \mathrm{~m}$, and the distance from the drainage pipes to the edge of each plot was at least $2 \mathrm{~m}$. The strips of land between the plots that were not irrigated functioned as indirect buffer strips. However, there was no control, with respect to root growth, beyond the border of each plot.

The eight plots were planted with four different species in 2003; two plots were planted with bare-rooted 50-to-80-cm-high $A$. glutinosa; two plots were planted with approximately $50-\mathrm{cm}$-high $S$. schwerinii $\times$ viminalis; two were sown with $L$. perenne seeds; and two were sown with $P$. arundinacea seeds. Salix schwerinii $\times$ viminalis planting was performed in a double-row system, with an approximate spacing of 0.75 and $1.5 \mathrm{~m}$, respectively, between the rows and approximately $0.6 \mathrm{~m}$ within the row, resulting in a plant density of approximately 1.6 plants $/ \mathrm{m}^{2}$. The plant density for A. glutinosa was roughly 1 plant $/ \mathrm{m}^{2}$. The grasses were sown so that complete ground cover was achieved rapidly. Two replicates for each planted strip were considered appropriate, because the case study site was sufficiently homogenous throughout the soil profile.

The study site was left to mature until early spring 2005. By then, A. glutinosa and $S$. schwerinii $\times$ viminalis had reached a height between 1.5 and $1.8 \mathrm{~m}$. Lolium perenne had a height of approximately $0.4 \mathrm{~m}$, and $P$. arundinacea measured $0.5 \mathrm{~m}$. A plastic hose was placed on the surface of the plots for irrigation purposes. The hose was laid down in two arms on every plot, parallel to and between the drainage pipes. The hose was perforated to allow the irrigation water to trickle out as uniformly over each plot as practically possible. The drainage water was collected by the below-ground pipe system, which introduced preferential flow conditions, as a result of low flow resistance within the pipes compared with the soil.

A previous study by Jonsson et al. (2006), discussing the runoff quality at this site, showed that the runoff was too low in nitrogen (approximately $1.3 \mathrm{mg} / \mathrm{L}$ ) compared with carbon and phosphorus to allow for sufficient biodegradation to take place (Scholz, 2006). To address this potential problem, the plots were fertilized with $80 \mathrm{~kg}-\mathrm{N} / \mathrm{ha}$ in early July 2005. Each plot received $20 \mathrm{~kg}$ of fertilizer ( $15.5 \%$ nitrogen and $18 \%$ potassium) comprising nitrate of lime (nitrocalcite) and other nutrients. No fertilizer was applied thereafter. The fertilizer contained no phosphorus and no organic matter.

During all sprinkling seasons, the plots were irrigated with log yard runoff, which originated from the adjacent sawmill, where logs of Picea abies (L.) Karst (Norway spruce) were stored on an asphalted log yard comprising 8 ha $\left(80000 \mathrm{~m}^{2}\right)$. During the sprinkling seasons in 2005, 2006, and 2007, the plots were irrigated with 8,12 , and $12 \mathrm{~mm} / \mathrm{d}$, respectively. The irrigation started at 8:00 a.m. and continued until the preset amount of water had been released, that is, until approximately 11:20 a.m. in 2005 and 1:00 p.m. in 2006 and 2007.

A weather-monitoring station was placed directly at the study site and connected to a data logger. The estimated mean annual precipitation for the area is $600 \mathrm{~mm}$ (based on a 30-year mean of a nearby weather station), and the approximate mean temperature is $5^{\circ} \mathrm{C}$ (SMHI, 2009). During the periods when log yard runoff was infiltrated at the site, data obtained from the station showed that the mean daily rainfalls and temperatures were 1.2, 2.4, and $1.6 \mathrm{~mm}$, and $12.6,14.3$, and $13.3^{\circ} \mathrm{C}$ in 2005,2006 , and 2007 , respectively. Log yard runoff was infiltrated during the log- sprinkling season, which lasts from approximately the end of April to the beginning of October. Analytical procedures applied were based on American Standard Methods (APHA et al., 1998).

\section{Results and Discussion}

Log Yard Runoff Compared with Drainage Water. Contaminant means and standard deviations for the log yard runoff and the drainage water from the plots have been summarized in Table 1. A comparison based on a one-way analysis of variance (ANOVA) between irrigation and drainage water for mean concentrations of total carbon, total inorganic carbon (TIC), total organic carbon (TOC), total phosphorus, and TSS for the four different species (two plots per species) was performed. The ANOVA showed that total carbon, TOC, and total phosphorus concentrations in the captured drainage water were lower and significantly different $(p<0.05)$ from the log yard runoff during the entire study period. This confirms that infiltration can be used successfully as a treatment method to reduce organic matter and phosphorus in $\log$ yard runoff, but findings indicate that the treatment efficiency over time could be limited for phosphorus.

For TIC, there was no significant treatment effect. Furthermore, the infiltration of the runoff also did not result in a statistically significant decrease in TSS concentrations. Despite the clear differences in mean concentrations of TSS in the log yard runoff and the drainage water from the planted plots (Table 1), the difference was not statistically significant in 2006. The low number of runoff samples $(n=4)$ and the generally high variability of TSS in the drainage water may explain the lack of statistical significance at $p<0.05$.

In 2007, the infiltration did not lead to a decrease in TSS concentrations. On the contrary, the concentrations in the drainage water were higher than in the runoff for four of the eight plots, possibly because of a breakthrough of partly degraded organic matter, such as detritus and litter (Scholz, 2006).

The $\mathrm{pH}$ values were slightly higher for the drainage water (annual means $=6.8$ to 7.5 ) compared with the log yard runoff (annual means $=6.3$ to 7.4 ). However, both the runoff and the drainage water were in the range of what is commonly interpreted as an expected $\mathrm{pH}$ range (6 to 8) for receiving watercourses (Scholz, 2006). The drainage water generally had lower concentrations of total nitrogen (annual means $=0.8$ to 3.4 ) than the $\log$ yard runoff (annual means $=1.3$ to 4.1 ). Previous studies have shown that the concentration of total nitrogen in log yard runoff generally is low and that no treatment to reduce the concentration is necessary, except when the receiving watercourse is classified as "very nitrogen vulnerable" (Hedmark and Scholz, 2008). On the contrary, in this study, the soil was fertilized with nitrate in 2005. Modest fertilization was undertaken to prevent a shortage of bioavailable nitrogen, which could have led to reduced plant growth.

Comparison of Drainage Water from the Different Plots. The results from the infiltration experiment were analyzed to assess if there were any statistically significant differences in treatment efficiency for the different plant species. However, the concentrations of TOC, total phosphorus, and TSS in the drainage water from the plots with different plant species did not differ significantly at $p<0.05$. The fact that the use of different plants did not significantly affect the removal efficiency (particularly regarding total phosphorus and TOC) strengthens the assumption that the microbial biomass contributed to the

Water Environment Research, Volume 82-Copyright (c) 2010 Water Environment Federation Uncorrected Page Proofs 
Table 1-Water quality parameters for the inflow and outflow of experimental soil infiltration systems planted with different species.

\begin{tabular}{|c|c|c|c|c|c|c|c|c|c|c|c|c|c|}
\hline \multirow[b]{2}{*}{ Sampling water type } & \multirow[b]{2}{*}{ Statistics* $^{*}$} & \multicolumn{2}{|c|}{$\begin{array}{l}\text { Total carbon } \\
(\mathrm{mg} / \mathrm{L})\end{array}$} & \multicolumn{2}{|c|}{ TIC (mg/L) } & \multicolumn{3}{|c|}{ TOC (mg/L) } & \multicolumn{3}{|c|}{$\begin{array}{l}\text { Total phosphorus } \\
\text { (mg/L) }\end{array}$} & \multicolumn{2}{|c|}{ TSS } \\
\hline & & 2006 & 2007 & 2006 & 2007 & 2005 & 2006 & 2007 & 2005 & 2006 & 2007 & 2006 & 2007 \\
\hline \multirow[t]{3}{*}{ Irrigation water (inflow) } & Mean & 218.4 & 246.0 & 28.5 & 21.5 & 120.3 & 171.6 & 224.5 & 1.2 & 1.5 & 2.3 & 108.0 & 117.1 \\
\hline & $\begin{array}{l}\text { Standard } \\
\text { deviation }\end{array}$ & 79.84 & 64.16 & 24.80 & 4.59 & 44.88 & 73.33 & 65.29 & 0.19 & 0.58 & 1.11 & 39.23 & 63.32 \\
\hline & $n$ & 3 & 7 & 3 & 7 & 5 & 6 & 7 & 5 & 6 & 7 & 4 & 7 \\
\hline \multirow{3}{*}{$\begin{array}{l}\text { Outflow for Alnus } \\
\text { glutinosa }\end{array}$} & Mean & 109.4 & 131.6 & 20.9 & 23.3 & 52.0 & 88.5 & 108.4 & 0.6 & 0.8 & 1.2 & 68.4 & 156.0 \\
\hline & $\begin{array}{l}\text { Standard } \\
\text { deviation }\end{array}$ & 49.37 & 42.18 & 5.09 & 3.62 & 13.39 & 45.89 & 41.26 & 0.29 & 0.27 & 0.76 & 38.66 & 209.63 \\
\hline & $n$ & 16 & 14 & 16 & 14 & 7 & 16 & 14 & 7 & 16 & 14 & 16 & 14 \\
\hline \multirow{3}{*}{$\begin{array}{l}\text { Outflow for Salix } \\
\text { schwerinii } \times \text { viminalis }\end{array}$} & Mean & 114.4 & 134.0 & 23.0 & 24.8 & 46.7 & 91.3 & 109.1 & 0.6 & 0.9 & 1.4 & 54.8 & 144.4 \\
\hline & $\begin{array}{l}\text { Standard } \\
\text { deviation }\end{array}$ & 47.06 & 48.37 & 4.43 & 4.88 & 14.29 & 47.79 & 48.68 & 0.14 & 0.42 & 0.75 & 36.64 & 171.37 \\
\hline & $n$ & 16 & 14 & 16 & 14 & 7 & 15 & 14 & 7 & 15 & 14 & 15 & 14 \\
\hline \multirow{3}{*}{$\begin{array}{l}\text { Outflow for Phalaris } \\
\text { arundinacea }\end{array}$} & Mean & 108.8 & 144.4 & 21.3 & 22.9 & 43.0 & 87.5 & 121.5 & 0.5 & 0.9 & 1.5 & 70.9 & 125.1 \\
\hline & $\begin{array}{l}\text { Standard } \\
\text { deviation }\end{array}$ & 41.54 & 40.62 & 5.37 & 3.46 & 7.07 & 40.28 & 38.46 & 0.17 & 0.49 & 0.52 & 68.92 & 106.59 \\
\hline & $n$ & 16 & 14 & 16 & 14 & 8 & 16 & 14 & 8 & 16 & 14 & 16 & 14 \\
\hline \multirow{3}{*}{$\begin{array}{l}\text { Outflow for Lolium } \\
\text { perenne }\end{array}$} & Mean & 100.1 & 121.7 & 18.1 & 21.4 & 43.1 & 82.0 & 100.3 & 0.5 & 0.7 & 1.2 & 51.3 & 87.7 \\
\hline & $\begin{array}{l}\text { Standard } \\
\text { deviation }\end{array}$ & 44.46 & 43.06 & 6.71 & 3.78 & 12.23 & 41.96 & 41.33 & 0.17 & 0.37 & 0.57 & 22.23 & 51.02 \\
\hline & $n$ & 16 & 14 & 16 & 14 & 7 & 16 & 14 & 7 & 16 & 14 & 15 & 14 \\
\hline
\end{tabular}

${ }^{*} n=$ sample number.

purification performance (Scholz, 2006). However, no further investigations of bioactivity within the soil columns of the plots were undertaken.

There also were no differences in concentrations of total carbon for the species in the infiltration experiment. However, a twosample $t$-test showed that the drainage water from the plots vegetated with $S$. schwerinii $\times$ viminalis had significantly higher concentrations of TIC than the drainage water from the plots planted with $L$. perenne. This was unexpected, because the infiltration treatment had no removal effect on TIC. This difference between the plant species could not be explained in this case study.

A statistical comparison with the two-sample $t$-test also was made for the water quality parameters of the drainage water from the plots vegetated with tree species (A. glutinosa and $S$. schwerinii $\times$ viminalis) compared with grasses (L. perenne and $P$. arundinacea). None of the assessed parameters (total carbon, TIC, TOC, total phosphorus, and TSS) were statistically significantly different $(p<0.05)$.

Comparison of Treatment Efficiencies. The findings confirmed that the infiltration treatment efficiency for log yard runoff was high with regard to TOC and that the removal of total phosphorus was high and relatively continuous during the experiment (Table 1). The removal of total carbon was relatively high, but the infiltration treatment was not successful for TIC and TSS. Furthermore, the treatment efficiencies decreased slightly, but not significantly, for TOC and total phosphorus during the study. However, the loads increased considerably from year to year, and the amount of TOC and total phosphorus that was removed by the system also increased. The TOC loads on the system were 1630,3461 , and $4124 \mathrm{~kg} / \mathrm{ha}$ in 2005,2006 , and 2007 , respectively. The loads of total phosphorus for these years were 15,30 , and $43 \mathrm{~kg} / \mathrm{ha}$, respectively.
The treatment efficiencies of TSS decreased in 2007, which cannot be explained by an increased load of suspended solids in the irrigation water. The load of suspended solids only increased by $1.3 \%$ from 2006 to 2007 . The change from sink to source of TSS cannot be explained by the small increase in load. However, it is known that some infiltration systems are sources for TSS, which is common for vertical downflow filtration systems (AlSenafy and Al-Otaibi, 2002; Scholz, 2003).

\section{Conclusions and Further Research}

The treatment efficiency for total phosphorus was relatively good, but further field-scale experiments are required to determine the longterm treatment effect at different phosphorus loads. Findings indicated no significant difference in treatment efficiencies when comparing four species of plants with each other. There also were no significant differences between the tree and grass species. The research indicates that, under similar boundary conditions, an area of approximately 0.5 ha of infiltration system would be required for every $10000 \mathrm{~m}^{3}$ of yearly runoff from a $\log$ yard, to achieve the same retention of contaminants as in this study. Further research is required to address the inherent limitations of the study (i.e., no buffer strips between the plots, limited number of replicate plots, no unplanted control, and no nutrient analysis within each soil column), which was not designed as a rigorous experiment, but rather as an applied evaluation.

\section{Credits}

The authors thank Setra Trävaror AB (Heby, Sweden) and Karl Erik Önnesjös stiftelse för vetenskaplig forskning och utveckling (Karl Erik Önnesjö's Foundation for Scientific Research and Development) (Norköping, Sweden) for the financial support given during this study. The authors are grateful for the invaluable fieldwork and technical support provided by Richard Childs and 
Gunnar Torstensson (Swedish University of Agricultural Sciences, Uppsala, Sweden), and thank Karin Tonderski (Linköping University, Linköping, Sweden) and Maria Jonsson (Swedish University of Agricultural Sciences) for their guidance.

Submitted for publication February 10, 2009; revised manuscript submitted December 4, 2009; accepted for publication December 9, 2009.

\section{References}

Al-Senafy, M.; Al-Otaibi, M. (2002) Replenishing Groundwater Aquifers Through Recharge of Treated Wastewater. Acta Universitatis Carolinae Geologica, 46 (2-3), 674-676.

American Public Health Association; American Water Works Association; Water Environment Federation (1998) Standards Methods for the Examination of Water and Wastewater, 20th ed.; American Public Health Association: Washington, D.C.

Hedmark, A.; Scholz, M. (2008) Review of Environmental Effects and Treatment of Runoff from Storage and Handling of Wood. Bioresour. Technol., 99 (14), 5997-6009.
Hedmark, A.; Scholz, M.; Elowson, T. (2009) Treatment of Log Yard Runoff Impacted by Aged Logs in a Free Water Surface Constructed Wetland. Environ. Eng. Sci., 26 (11), 1623-1632.

Jonsson, M.; Dimitriou, I.; Aronsson, P.; Elowson, T. (2006) Treatment of Log Yard Runoff by Irrigation of Grass and Willows. Environ. Pollut., 139 (1), 157-166.

Scholz, M. (2003) Performance Predictions of Mature Experimental Constructed Wetlands, which Treat Urban Water Receiving High Loads of Lead and Copper. Water Res., 37 (6), 1270-1277.

Scholz, M. (2006) Wetland Systems to Control Urban Runoff; Elsevier: Amsterdam, Netherlands.

SMHI (2009) Dataserier med normalvärden för perioden 1961-1990 (Data Series with Normal Values for the Period 1961-1990). Sveriges Meteorologiska och Hydrologiska Institut (Swedish Meteorological and Hydrological Institute): Norrköping, Sweden, http://www.smhi. se/klimatdata/meteorologi/temperatur/dataserier-med-normalv\%C3\%A4rden-1.7354 (accessed Jan. 18, 2010).

Woodhouse, C.; Duff, J. B. S. (2004) Treatment of Log Yard Runoff in an Aerobic Trickling Filter. Water Qual. Res. J. Can., 39 (3), 230 236. 